\title{
PATTERN OF OVARIAN TUMORS: REPORT OF 15 YEARS EXPERIENCE AT LIAQUAT UNIVERSITY JAMSHORO
}

\author{
Naseer A. Shaikh, Fazila Hashmi and Rukhsana Parveen Samoo
}

\begin{abstract}
OBJECTIVE: To evaluate the morphological pattern of different ovarian tumors among the rural population of Sindh.

Setting: Department of Pathology, Liaquat University of Medical and Health Sciences, Jamshoro, Sindh - Pakistan over a period of fifteen years.

DESIGN: A descriptive study.

MATERIAL AND METHODS: All specimens, received by the department were examined, however, only those specimens that belonged to interior of Sindh were included in the study. Data were recorded on a proforma and were analyzed statistically.

RESULTS: In total, 694 ovarian tumor specimens were examined. Majority of these tumors was benign (68.28\%). Tumors of low malignant potential (borderline) were $<01 \%$. Those with frank malignant features were $31 \%$. On cytological basis, tumors taking origin from surface epithelium were most frequent, constituting $81 \%$ of the total. Germ cell tumors were second in the row with percentage of 10.95 . Metastatic deposits were seen in only $1.58 \%$ of the cases.

CONCLUSION: Ovarian tumors are quite common in this set up. A relatively high number of malignancies was observed in this study and the etiology of which is yet to be established.
\end{abstract}

KEY WORDS: Ovary. Tumors. Malignancy.

\section{INTRODUCTION}

Ovarian tumors affect a significant number of female populations. They are not always malignant. But the feeling of harboring a tumor is, fearsome. Among all types of ovarian tumors registered, the incidence of malignancy is about $15-20 \%$ in different parts of world. ${ }^{1}$ These tumors behave in a diverse way and generally escape the detection until they attain a larger size. ${ }^{2}$ It is also true for their malignant counterparts, which makes the disease incurable. It ranks as the fourth most common malignancy of the females after cancer of the breast, uterus and oral cavity. ${ }^{3}$

\section{MATERIAL AND METHODS}

This study was carried out from January 1990 to December 2004 at the Department of Pathology, Liaquat University of Medical and Health Sciences, Jamshoro. All the specimens of ovarian tumor, registered for histopathological examinations were included in the study, irrespective of their clinical pattern and stage of the disease. The data were collected on a proforma and included the relevant information about the patients, the provisional diagnosis, operative findings, and the histopathological analysis. Specimens without the desired information were excluded from the study. The specimens were stained with hematoxylin and eosin and examined by a team of histopathologists. Later on, these were reviewed by the author.

\section{RESULTS}

During the course of study, a total of 694 specimens were examined. Out of those, $477(68.73 \%)$ were benign as judged by histopathological examinations. Only 5(<1\%) were borderline. Whereas, 215 (30.96\%) fulfilled the criteria for malignancy. Morphologically, tumors originating from surface epithelium ranked first. Most of them were benign i.e. 412 (59.36\%), very few borderline $5(<1 \%)$ and $145(20.9 \%)$ showed malignant features of different grades (Table I). Further subclassifying the tumors originating from surface epithelium, 353 (50.8\%) were serous, 206(29.6\%) mucinous, and $3(0.43 \%)$ were Brenner tumors. Germ cell tumors were next in descending order. They constituted 76 $(11 \%)$ of the total number. Among these, majority were benign $50(7.2 \%)$. Malignant features were seen in $26(3.74 \%)$ of total number. Majority was teratomas i.e. 54(7.8\%), followed by $19(2.7 \%)$ dysgerminomas, 2 $(0.28 \%)$ choriocarcinomas, and $1(0.14 \%)$ yolk sac tumor in decreasing order of frequency. Neoplastic development from sex cords and stromal elements, were $37(5.3 \%)$ with $25(3.6 \%)$ showing malignant features. The remaining $12(1.7 \%)$ specimens were benign. Miscellaneous and rare tumors were also observed and included carcinosarcoma 2(0.28\%), Non Hodgkin's Lymphoma 2(0.28\%) and undifferentiated malignant tumor $4(0.57 \%)$ cases respectively. Krukenburg's tumor (metastatic deposits) was found to affect $11(1.58 \%)$ out of 694 specimens. 
TABLE I: HISTOLOGICAL PATTERN OF TUMORS

\begin{tabular}{|c|c|c|c|c|c|c|c|c|}
\hline \multirow[t]{2}{*}{ Microscopic Type } & \multicolumn{2}{|c|}{ Benign and Malignant } & \multicolumn{2}{|c|}{ Benign Tumors } & \multicolumn{2}{|c|}{ Malignant Tumors } & \multicolumn{2}{|c|}{$\begin{array}{l}\text { Borderline } \\
\text { Tumors }\end{array}$} \\
\hline & Number & $\%$ & Number & $\%$ & Number & $\%$ & Number & $\%$ \\
\hline $\begin{array}{l}\text { EPITHELIAL TUMORS } \\
\text { Serous Tumors } \\
\text { Mucinous Tumors } \\
\text { Brenner Tumors }\end{array}$ & $\begin{array}{c}562 \\
353 \\
206 \\
03\end{array}$ & $\begin{array}{c}81.0 \\
50.8 \\
29.6 \\
0.4\end{array}$ & $\begin{array}{c}412 \\
292 \\
117 \\
03\end{array}$ & $\begin{array}{c}59.36 \\
42.07 \\
16.85 \\
0.43\end{array}$ & $\begin{array}{l}145 \\
61 \\
84 \\
---\end{array}$ & $\begin{array}{c}2.89 \\
8.78 \\
12.11 \\
---\end{array}$ & $\begin{array}{l}05 \\
--- \\
05 \\
---\end{array}$ & $\begin{array}{c}\mathbf{0 . 7 2} \\
--- \\
0.72 \\
---\end{array}$ \\
\hline $\begin{array}{l}\text { GERM CELL TUMORS } \\
\text { Teratoma } \\
\text { Dysgerminoma } \\
\text { Choriocarcinoma } \\
\text { Yolk sac tumor }\end{array}$ & $\begin{array}{l}76 \\
54 \\
19 \\
02 \\
01\end{array}$ & $\begin{array}{c}10.95 \\
7.77 \\
2.7 \\
0.28 \\
0.14\end{array}$ & $\begin{array}{l}50 \\
50 \\
--- \\
---\end{array}$ & $\begin{array}{l}7.2 \\
7.2 \\
--- \\
---\end{array}$ & $\begin{array}{l}26 \\
04 \\
19 \\
02 \\
01\end{array}$ & $\begin{array}{l}3.74 \\
0.58 \\
2.73 \\
0.28 \\
0.14\end{array}$ & $\begin{array}{l}--- \\
--- \\
--- \\
--- \\
---\end{array}$ & $\begin{array}{l}--- \\
--- \\
--- \\
-- \\
---\end{array}$ \\
\hline $\begin{array}{l}\text { SEX CORD \& } \\
\text { STROMAL TUMORS } \\
\text { Granulosa cell Tumors } \\
\text { Theca cell tumors } \\
\text { Fibroma }\end{array}$ & $\begin{array}{l}37 \\
25 \\
03 \\
09\end{array}$ & $\begin{array}{c}5.03 \\
\\
3.6 \\
0.4 \\
1.29\end{array}$ & $\begin{array}{l}12 \\
--- \\
03 \\
09\end{array}$ & $\begin{array}{l}1.7 \\
--- \\
0.41 \\
1.29\end{array}$ & $\begin{array}{l}25 \\
25 \\
--- \\
---\end{array}$ & $\begin{array}{c}3.6 \\
3.6 \\
--- \\
---\end{array}$ & $\begin{array}{l}--- \\
--- \\
--- \\
---\end{array}$ & $\begin{array}{l}--- \\
--- \\
--- \\
---\end{array}$ \\
\hline $\begin{array}{l}\text { OTHERS } \\
\text { Carcinosarcoma } \\
\text { Lymphoma (NHL) } \\
\text { Undifferentiated }\end{array}$ & $\begin{array}{l}08 \\
02 \\
02 \\
04\end{array}$ & $\begin{array}{l}1.15 \\
0.27 \\
0.27 \\
0.57\end{array}$ & $\begin{array}{l}--- \\
--- \\
--- \\
---\end{array}$ & $\begin{array}{l}--- \\
--- \\
--- \\
---\end{array}$ & $\begin{array}{l}08 \\
02 \\
02 \\
04 \\
---\end{array}$ & $\begin{array}{l}1.15 \\
0.27 \\
0.27 \\
0.57 \\
---\end{array}$ & $\begin{array}{l}--- \\
--- \\
--- \\
--- \\
---\end{array}$ & $\begin{array}{l}--- \\
-- \\
--- \\
-- \\
---\end{array}$ \\
\hline METASTATIC & 11 & 1.58 & --- & --- & 11 & 1.58 & --- & --- \\
\hline TOTAL & 694 & 99.96 & 474 & 68.25 & 215 & 30.96 & 05 & 0.72 \\
\hline
\end{tabular}

\section{DISCUSSION}

Gynaecological departments receive their major load due to ovarian diseases. Because of the anatomical location, these tumors may remain unnoticed for a long period of time. These tumors cause abdominal pain and abdominal distension in majority of the cases. ${ }^{4}$ Based on histological pattern, these tumors are divided into benign, borderline and malignant. This is true for all the primary morphological variants. The common variants are epithelial cell tumors, germ cell tumors, and interstitial cell tumors. The ovary is the favorite site to get metastatic deposits from other abdominal cancers.

In the present study, majority of tumors was benign $(68.7 \%)$. The frequency of benign tumors was lower vis-à-vis to other studies conducted in different parts of the country. ${ }^{5,6}$ The frequency of malignant tumors in this study was $31 \%$. This is higher than what has been reported by most of the authors in the country, Ahmed et $\mathrm{al}^{7}$ being an exception. This is twice as high as reported incidence world-wide. ${ }^{8}$ The borderline tumors in this study were $05(<1 \%)$. As for as the histological variety is concerned, we observed that tumors originating from the surface epithelium were commonest among all. This observation is similar to other studies conducted in Pakistan and abroad. ${ }^{9,10}$ Next were germ cell tumors 76(10.95\%) and their incidence correlated with other studies mentioned above. Sex cord and stromal cell tumors were $37(5.03 \%)$.

The data available from this study can help in recognizing the pattern of ovarian tumors prevalent in this part of the world. Whether the benign tumor arises de novo or the benign transforms into malignant is the subject of ongoing debate and research. ${ }^{11}$ This is probably one of the reasons, we have observed an increased incidence of malignancy in our set up. But to confirm this observation further work and investigations are needed. Based on the results of this study, it is evident that, early diagnosis is crucial to help in decreasing morbidity and mortality among these patients. Therefore, we recommend that identification of known risk factors like familial predisposition, nullipar- 
ity and previous history of benign ovarian diseases ${ }^{12}$ in high-risk individuals may be beneficial.

\section{CONCLUSION}

It is concluded from this study that, on morphological grounds, tumors taking origin from surface epithelium are the common variant. Majority of them being benign, but a higher incidence of malignancy has also been observed in our set up. This is an alarming finding. It is therefore suggested that, efforts must be made to identify the risk factors.

\section{REFERENCES}

1. Naheed I, Malik S, Shaukat MS. Review of Ovarian Tumors. Ann King Edward Med Coll. 2001; 7 (3): 180-2.

2. Zafar FA, Fazil A, Asifa A, Karim A, Akmal N. Clinical manifestations of benign ovarian tumors. Ann King Edward Med Coll. 2005; 11(3): 258-9.

3. Rashid S, Sarwar G, Ali A. A Clinico-Pathological Study of Ovarian Cancer. Mother \& Child. 1998; 36(1): 117-125.

4. Christopher P. Crum. Female Genital Tract. In: Kumar, Abbas, Fausto, eds. Robbins \& Cotran Pathologic Basis of Disease. $7^{\text {th }}$ edition. WB Saunders, Philadelphia, 2004: Pp. 1059-1117.

5. Sultana A, Hasan S, Siddiqui QA. Ovarian tumors: A five years retrospective study at Abbasi Sha- heed Hospital, Karachi. Pak J Surg. 2005; 21(1): 37-40.

6. Alam I, Waqar F, Khan A, Begum N. Prevalence and Management of Ovarian Tumors in Women and Children Hospital, Abbottabad. J Ayub Med Coll Abottabad. 2001; 13(2): 19-21.

7. Ahmed M, Malik TM, Saeed A, Mubarik A. Clinicopathological study of 762 ovarian neoplasms at Army Medical College, Rawalpindi. Pak J Pathol. 2004; 15(4): 147-52.

8. Piver MS, Baker TR, Piedmonte M, Sandeeki AM. Epidemiology and etiology of Ovarian Cancer. Semin Oncol. 1991; 18:177-85.

9. Ahmad Z, Kayani N, Hasan S, Muzaffar S, Gill M. Histological pattern of ovarian neoplasms. J Pak Med Assoc. 2000; 50(12): 416-9.

10. Malik IA. A Prospective Study of Clinicopathological Features of Epithelial Ovarian Cancer in Pakistan. J Pak Med Assoc. 2002; 52(4): 155-8.

11. Brinton LA, Sakoda LC, Sherman ME, Frederiksen K, Kjaer SK, Graubard BI, et al. Relationship of benign gynecologic diseases to subsequent risk of ovarian and uterine tumors. Cancer Epidemiol Biomarkers Prev. 2005; 14(12): 2929-35.

12. Borgfeldt C, Andolf E. Cancer risk after hospital discharge diagnosis of benign ovarian cysts and endometriosis. Acta Obstet Gynecol Scand. 2004; 83(4): 395-400.

AUTHOR AFFILIATION:
Dr. Naseer A. Shaikh (Corresponding Author)
Assistant Professor, Department of Pathology
Liaquat University of Medical \& Health Sciences
(LUMHS) Jamshoro, Sindh - Pakistan.
Dr. Fazila Hashmi
Resident, Department of Surgery
LUMHS Jamshoro, Sindh - Pakistan.
Dr. Rukhsana Parveen Samoo
Lecturer, Department of Pathology
LUMHS Jamshoro, Sindh - Pakistan.

